\title{
Does the disclosure of unsolicited sovereign rating status affect bank ratings?
}

\author{
Patrycja Klusak $^{\mathrm{a}, *}$, Rasha Alsakka ${ }^{\mathrm{b}}$, Owain ap Gwilym

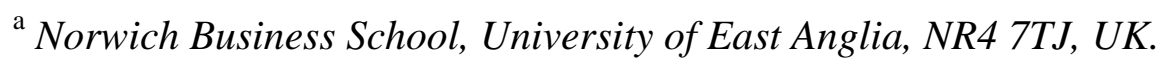 \\ ${ }^{\mathrm{b}}$ Bangor Business School, Bangor University, LL57 2DG, UK
}

This version: $16^{\text {th }}$ August 2016

\begin{abstract}
This paper integrates three themes on regulation, unsolicited credit ratings, and the sovereignbank rating ceiling. We reveal an unintended consequence of the EU rating agency disclosure rules upon rating changes, using data for S\&P-rated banks in 42 countries between 2006 and 2013. The disclosure of sovereign rating solicitation status for 13 countries in February 2011 has an adverse effect on the ratings of intermediaries operating in these countries. Conversion to unsolicited sovereign rating status transmits risk to banks via the rating channel. The results suggest that banks bear a penalty if their host sovereign does not solicit its ratings.
\end{abstract}

JEL classification: G15; G24.

Keywords: Bank Ratings; Rating agency regulation; Unsolicited ratings; Sovereign-bank rating channel.

* Corresponding author. Tel.: +44 (0) 1603591401.

E-mail addresses: p.klusak@uea.ac.uk (P. Klusak), r.alsakka@bangor.ac.uk (R. Alsakka), owain.apgwilym@bangor.ac.uk (O.ap Gwilym). 


\title{
Does the disclosure of unsolicited sovereign rating status affect bank ratings?
}

\begin{abstract}
This paper integrates three themes on regulation, unsolicited credit ratings, and the sovereignbank rating ceiling. We reveal an unintended consequence of the EU rating agency disclosure rules upon rating changes, using data for S\&P-rated banks in 42 countries between 2006 and 2013. The disclosure of sovereign rating solicitation status for 13 countries in February 2011 has an adverse effect on the ratings of intermediaries operating in these countries. Conversion to unsolicited sovereign rating status transmits risk to banks via the rating channel. The results suggest that banks bear a penalty if their host sovereign does not solicit its ratings.
\end{abstract}

Keywords: Bank Ratings; Rating agency regulation; Unsolicited ratings; Sovereign-bank rating channel.

This version: $16^{\text {th }}$ August 2016 


\section{Introduction}

Credit Rating Agencies (CRAs) play a prominent role in modern financial markets. Globalization and the increasing complexity of investment products have triggered a growing demand for widely recognised risk assessment. Sovereign ratings serve as a basis for evaluating the creditworthiness of a country, and thereby influence long-term investment and lending decisions across borders. Rating downgrades have major implications for financial markets and institutions, including rising costs of credit and hindered market access (e.g. BIS, 2011; Alsakka, ap Gwilym, and Vu, 2014; Correa, Lee, Sapriza, and Suarez, 2014).

The global financial crisis brought CRAs renewed publicity and ongoing scrutiny by regulators. CRAs were blamed for worsening economic conditions by downgrading some sovereigns too quickly and too severely. The overreliance on ratings by market participants led to cliff effects whereby downgrades had a disproportionate effect. The situation in Europe has further emphasised the hazardous effects of negative spillovers while highlighting interconnectedness between international financial institutions (e.g. Arezki, Candelon, and Sy, 2011). The influence of ratings on global financial stability has become a major concern. In 2009, the European Commission (EC) implemented a new set of regulations aimed at CRAs including registration procedures, governance requirements, internal controls, disclosure rules and improvements in rating methodologies (CRA I Regulation). ${ }^{1}$ This regulation was amended in May 2011 (CRA II Regulation) and in November 2011 (CRA III Regulation). The responsibility for supervising and certifying CRAs was handed to the European Securities and Markets Authority (ESMA) in July 2011. This paper draws attention to the disclosure rules with particular focus on Article 10 (5) of the EU Regulation 1060/2009, which requires that when a CRA issues an unsolicited rating, it needs to be

\footnotetext{
${ }^{1}$ Regulation (EC) No 1060/2009 of the European Parliament and of the Council of 16 September 2009 on credit rating agencies.
} 
identified as such. ${ }^{2}$ As a result of implementing the Article in February 2011, S\&P disclosed the conversion to unsolicited status of 14 rated sovereign governments (S\&P, 2011a, b, c). Unsolicited ratings are one of the most controversial features of the CRA business. Prior literature (e.g. Poon, Lee, and Gup, 2009; Bannier, Behr and Güttler, 2010; Van Roy, 2013) finds that banks and corporations rated on an unsolicited basis have significantly lower ratings. Concerns exist that unsolicited ratings are biased downward because CRAs are not compensated for their service. Additionally, policymakers have focused on this feature, because both solicited and unsolicited ratings are permitted for some regulatory uses.

The broad aim of this paper is to examine whether the disclosure rule on solicitation status achieves its objective of more credible rating services or has unintended consequences. Specifically, we investigate whether conversion to sovereign unsolicited rating status (induced by disclosure rules) results in lower bank ratings (in the re-designated unsolicited sovereign states). Previous literature on the controversies related to unsolicited (nonsovereign) ratings provides a theoretical framework (see Section 2.3). Additionally, it is well known that sovereign risk spills over to financial institutions through many channels (BIS, 2011; De Bruyckere, Gerhardt, Schepens, and Vennet, 2013; Alsakka, et al., 2014). Studying whether the mandatory disclosed unsolicited status of sovereign ratings transmits risk to banks is a key motivation for this research.

The novelty of this study derives from building on three streams of research, which meaningfully overlap and result in a synergy which has not been previously explored. The first theme relates to the unique opportunity to investigate the dynamics of rating solicitation for sovereigns. To the best of our knowledge, no prior study has investigated the rationale and impact of rating solicitation status for sovereigns. The existing literature concentrates on the solicitation of corporate and bank ratings (Poon, 2003; Poon et al., 2009; Bannier et al.,

\footnotetext{
${ }^{2}$ A solicited rating is a rating requested by the issuer who incurs the cost of the appraisal. An unanticipated (by the issuer) assessment by the CRA using public information about the issuer is known as an unsolicited rating.
} 
2010; Van Roy, 2013) yet it does not include any study of solicitation conversions. The second theme relates to the impact of sovereign ratings on bank ratings through the rating channel. This aspect of the paper builds on recent work (Alsakka et al., 2014; Huang and Shen, 2015) while adding a new dimension to the type of constraints imposed by sovereigns on banks via rating ceilings.

Thirdly, this paper considers the influence of the recent EU CRA regulation. To the best of our knowledge, there is no published empirical work on the effects of enhanced disclosure by CRAs introduced since 2009. Jorion, Liu, and Shi (2005) study the effect of U.S. Regulation Fair Disclosure (Reg FD), introduced in 2000, and find that both positive and negative rating changes have a stronger informational effect on stock prices after the Reg FD took effect. Poon and Evans (2013) find that the impact of rating downgrades on bond yield premia (after Reg FD) depends on the size of the firm. Studies on other forms of rating-related regulation focus on periods prior to the EU CRA regulation (e.g. Becker and Milbourn (2011) utilize a U.S. sample from 1995 to 2006).

The paper uses a large sample of 147 banks rated by S\&P incorporated in 42 countries in Europe, Asia-Pacific and Latin America for the period between 2006 and 2013. We apply an ordered probit model estimation, along with many robustness checks including placebo tests and matching exercises. We strongly endeavour to rule out the possibility of sample selection bias or that the observed phenomenon arises from events other than the adoption of EU disclosure rules for CRAs.

The results strongly suggest that disclosure of unsolicited sovereign status adversely influences bank ratings through the rating channel. Banks in countries converted to unsolicited status are more likely to be downgraded and less likely to be upgraded compared with banks in sovereigns which retained solicited ratings at all times. The marginal effects (MEs) analysis suggests that the former banks are $1.73 \%, 0.74 \%$ and $0.47 \%$ more likely to be 
downgraded by 1,2 and $\geq 3$ Comprehensive Credit Rating (CCR) points respectively. ${ }^{3}$ The significance of the MEs should be considered in relation to the total number of bank (sovereign) rating downgrades which represent $3.28 \%(2.73 \%)$ of all observations. Additionally, the analysis confirms a strong ceiling effect between sovereigns and banks. These findings have clear policy implications for regulators and banks, since there are potential costs to the institutions and the wider economies through this rating ceiling effect. The phenomenon represents an unintended consequence of regulation, and suggests a need for greater awareness of CRA rating policies in designing future regulation. Policymakers should take a closer look at unsolicited sovereign ratings and their implications. The findings of this study reveal an undesirable impact of recent regulatory developments on the European economy and will be informative in shaping future proposals.

The paper is structured as follows. Section 2 draws from prior theoretical and empirical literature to frame the research questions and the testable hypothesis. The data and descriptive statistics are discussed in Section 3. Section 4 discusses research methodologies, Sections 5 and 6 present the empirical results and Section 7 concludes the study.

\section{Literature review and hypothesis development}

\subsection{Bank credit ratings}

Reliance on bank ratings has grown in recent years, partly driven by increased and more complex financial transactions and by disintermediation. Simultaneously, deregulation and innovation (e.g. securitisation, derivatives) resulted in banks being bigger, more concentrated, complex and closely linked with the capital markets (Hau, Langfield, and Marques-Ibanez, 2013). Bank ratings impact the cost of issuing senior unsecured debt, which is the most important type of funding for intermediaries in the long run (Wyman, 2011). Bank ratings also influence the distribution of capital, risk and liquidity creation, e.g. bank ratings

\footnotetext{
${ }^{3}$ These figures relate to outlook action, watch event, and downgrade by one notch or more.
} 
are key determinants of the quality of banks' portfolios, the quality of collateral to obtain liquidity from central banks, and capital adequacy requirements. However, rating banks poses some difficulties for CRAs, given that banks are opaque and subject to a range of different risks. They are also exposed to asymmetric information and are under regulatory oversight.

Bank ratings reflect creditworthiness and are based on a 'through the cycle' perspective. Prior literature shows that bank ratings are driven not only by bank-specific factors but also by the macroeconomic environment and potential external support from the government. Caporale, Matousek and Stewart (2012) show that bank ratings are affected by banks' financial position and country of origin, whereby a bank in a less stable/developed/rich economy appears to have a lower rating. Shen, Huang, and Hasan (2012) show that banks with higher ratios of profitability, liquidity and capital adequacy and better ratios of efficiency (cost-to-income) and asset quality (loan loss provisions to net interest revenues) tend to be assigned higher ratings. The influence of financial ratios on bank ratings is greater in industrial or high-income countries than in emerging market countries. Hau et al. (2013) also find that bank characteristics significantly affect bank rating quality. They emphasise that the quality of banks' ratings increase with more traditional banking activities, while CRAs assign more favourable ratings to large banks and those banks that provide CRAs with a large quantity of securities rating business.

Banks are different to most other corporations in that governments are more likely to assist them due to their systemic importance. Governments might also limit the financial flexibility of intermediaries through regulatory means. Hence, sovereign risk is considered as a key factor determining a bank rating (Poon et al., 2009; Shen et al., 2012; Huang and Shen, 2015). Sovereign ratings typically represent an upper limit for the ratings assigned to nonsovereign issuers in the country. Although the sovereign rating ceiling technically no longer exists, there is evidence that sovereign ratings strongly affect the ratings of non-sovereigns 
(Borensztein, Cowan, and Valenzuela, 2013), and banks very rarely pierce the sovereign

\footnotetext{
${ }^{4}$ For example, when S\&P downgraded 15 Spanish banks' ratings on 13 February 2012, they stated that the 'The rating actions follow the lowering of the long- and short-term sovereign credit ratings on the Kingdom of Spain ... published Jan. 13, 2012'. Similarly, on 10 February 2012, S\&P lowered its ratings on 34 Italian financial institutions and stated that 'the downgrades follow the lowering of the unsolicited long- and short-term sovereign credit ratings on the Republic of Italy ... published Jan. 13, 2012.'
} 
The last channel relates to the fact that lower ratings of sovereigns are found to translate directly into lower bank ratings in that country (Alsakka et al., 2014; Huang and Shen, 2015). The spillover is known to occur for two reasons. Firstly, the lower sovereign ratings affect the cost of debt and equity funding. Arezki et al. (2011) show that sovereign rating changes affect bank stock index levels in Europe over the 2007-2010 period. Similarly, Caselli, Gandolfi, and Soana (2014) find evidence of significant bank losses following sovereign rating downgrades in the European market. Correa et al. (2014) find that banks which are expected to receive government support demonstrate lower stock returns after a sovereign rating downgrade, while Williams, Alsakka and ap Gwilym (2015) show that S\&P actions induce a significant impact on bank valuations in emerging markets. Further, BIS (2011) emphasises that sovereign debt concerns push up banks' funding costs. BIS (2011) show that in 2010 a large proportion (30\%, or 120 basis points) of the spread, between the bond yield and the swap rate of similar maturity, on bank bonds reflected the conditions of the sovereign (in terms of sovereign ratings and CDS premium).

Secondly, the ceiling effect arises because sovereigns have greater resources and policies at their disposal which mean that a higher non-sovereign rating is rarely justifiable. Borensztein et al. (2013) suggest that sovereign risk transmits onto non-sovereign issuers via the capital and other administrative controls and restrictive measures available to the government. Prohibitions against inflow and outflow of investment into the country (transfer and convertibility risk) restrain companies from repaying their external debt when the government reaches default or near default. In such a relationship, the non-sovereign debt always defaults when the state defaults, as it cannot access currency or transfer its funds outside the borders. Fitch (2012) suggest that sovereign actions such as altered regulated tariffs, deposit freezes, penalty taxation or expropriation are other reasons which justify the sovereign ceiling. Additionally, many banks participate in cross-holding claims of other 
intermediaries across countries, and thereby become exposed to one another (Arezki et al., 2011). Other channels include banking regulation, CDS contracts, and investment mandates (Sy, 2009).

\subsection{Theories of deflated unsolicited ratings}

Theoretical insights on deflated unsolicited ratings arise under three main concepts: (i) self-selection bias, (ii) strategic conservatism, and (iii) blackmail theory. ${ }^{5}$

Self-selection bias indicates that entities with unsolicited ratings who wish to convey a message that their creditworthiness is in fact better than stated will request solicited ratings. Once the rating improves, such entities benefit from a lower cost of capital. ${ }^{6}$ The overall reduction in cost explains the willingness of firms to incur fees for solicitation. Conversely, issuers which are aware of their weak creditworthiness, do not request and pay for a solicited rating (Fulghieri, Strobl, and Xia, 2014). Consequently, low quality issuers remain with their (relatively low) unsolicited ratings. Self-selection is thereby predicted to assist in reaching the most adequate credit appraisal for issuers regardless of the solicitation status. In our context, one could argue that a sovereign expecting a future rating downgrade would be more relaxed about an impending conversion to unsolicited status (e.g. not wishing to pay fees to a CRA if they consider a lower rating to be inevitable).

The exact opposite of this premise arises under the strategic conservatism theory. Bannier et al. (2010) suggest that unsolicited ratings might be driven by CRAs' "strategic considerations in the rating process" (p.264). When CRAs face a reduced information flow from an issuer, they might prefer to rate "too low" rather than "too favourably". These

\footnotetext{
${ }^{5}$ A fourth concept is the geographical discrimination theory. Li, Shin, and Moore (2006) conclude that raters outside Japan (Moody's and S\&P) do not reflect the keiretsu affiliation status. However, this is not applicable in this paper.

${ }^{6}$ According to Duff and Einig (2009), the CRAs allow borrowers to raise capital more cheaply by means of reducing asymmetric information between investors and debtors (i.e. CRAs reduce the risk premia of debt issues).
} 
authors argue that issuers who share the same creditworthiness can be assigned different ratings, based on different solicitation status. Those who do not mandate for ratings receive a (lower) unsolicited rating whereas those who purchase a rating obtain a (higher) solicited rating (after controlling for the economic and financial conditions of the borrower). Likewise, the same rating level assigned to both solicited and unsolicited borrowers conveys a message that the unsolicited issuer is in fact less risky than implied by its rating. However, this does not assist a non-sovereign with solicited ratings in our context. In a scenario where an issuer converts to unsolicited status, the CRA does not have access to private information and might therefore decide to rate lower after the conversion in order to ensure conservatism. Also, prior literature has not considered how this effect may proceed under the sovereign-bank ceiling e.g. a bank paying for its solicited rating might face a downgrade attributable to the sovereign's decision-making in opting for an unsolicited rating.

The blackmail theory assumes that CRAs might persuade issuers to purchase ratings, otherwise threatening them (indirectly) by releasing disproportionately low unsolicited ratings. The rationale suggests that when the issuer is not transparent and does not disclose information, the risk assessment is difficult to perform and therefore downward biased ratings are not prone to being questioned by market participants (Van Roy, 2013). Ramakrishnan and Thakor (1984) stipulate that blackmail is not a tenable position for the CRAs, since their reputational capital plays a more important role than any short-term financial gains. However, Bar-Isaac and Shapiro (2013) and Opp, Opp, and Harris (2013) argue that the reputational concerns of CRAs change over the business cycle. CRAs increase their ratings quality in low points of the economic cycle and relax them during booms. 


\subsection{Hypothesis}

Two streams of literature discussed above provide a potential explanation for differentials between ratings of banks incorporated in solicited versus unsolicited sovereigns. Firstly, the theories of downward biased ratings for unsolicited non-sovereigns provide reasons to believe that the solicitation status of sovereigns will impact their credit ratings. Secondly, the evidence that bank ratings are influenced by sovereigns through the rating channel (e.g. BIS, 2011; Alsakka et al., 2014) might lead the sovereign's solicitation status to become a concern for banks. Under the interaction of these effects, we propose:

Hypothesis: Bank ratings are more likely to be downgraded in countries whose sovereign rating status is converted to 'unsolicited'.

Such an effect has a negative impact on the funding costs of banks in that country. Investigation of the interplay between sovereigns and banks in this setting poses challenges in interpretation of the competing theories of unsolicited ratings (in Section 2.3). There is no literature (theoretical or empirical) which examines the issue of solicitation of sovereigns, not to mention the dynamics of any conversion in status. Individual governments do not reveal their rating subscription details and it is difficult to deduce whether self-selection plays a role in the status of sovereign ratings. On the other hand, sovereigns are relatively transparent in terms of their liability structures, unlike banks. Despite this, when a sovereign converts its solicitation status, the CRA might perceive a deficiency of soft information and start rating the sovereign more conservatively. The blackmail theory could offer a plausible explanation in a case where the issuer is less transparent (Van Roy, 2013). However, it is unlikely that a CRA providing services not only to a sovereign but also to a number of non-sovereigns in that constituency would threaten its current or potential clientele without genuine concern about harming its reputation (Ramakrishnan and Thakor, 1984). 


\section{Sample and data summary}

\subsection{Solicitation status}

The ratings and solicitation status for all sovereigns are obtained from S\&P publications. On $24^{\text {th }}$ February 2011, S\&P (2011a, b, c) released reports on conversions of solicitation status for: 1) seven European countries (Belgium, France, Germany, Italy, Netherlands, Switzerland, United Kingdom); 2) six Asia-Pacific countries (Australia, Cambodia, India, Japan, Singapore, Taiwan); and 3) U.S.A. The press releases from S\&P state: 'Standard \& Poor's is converting its issuer and issue ratings on Belgium, France, Germany, Italy, Netherlands, Switzerland, the U.K., and the European Central Bank (ECB) to "unsolicited", in light of the new European Union regulations' (S\&P, 2011a), and 'Standard \& Poor's is converting its issuer and issue ratings on Australia, Cambodia, India, Japan, Singapore, and Taiwan to "unsolicited"' (S\&P, 2011b). In addition, all the issue ratings are then withdrawn shortly after the conversion of the issuer rating to 'unsolicited', which lends support to there being a fundamental change in S\&P's relation with these sovereigns. ${ }^{7}$ For example, S\&P (2011b) states: 'On May 24, 2011, we will withdraw all our issue ratings on the debt of Japan, Singapore, and Taiwan'. Further, Argentina's solicitation status was converted on the $4^{\text {th }}$ April 2011 and was the final case arising from the regulatory requirements on disclosure during our sample period. U.S.A. is excluded from the reported results due to it having a high proportion (approx. 20\%) of all S\&P-rated financial institutions, which would distort the sample and dominate any evidence on the research question. ${ }^{8}$

\footnotetext{
${ }^{7}$ The withdrawal of issue ratings shortly after the conversion of issuer rating to unsolicited status has no effect on our sample or our empirical analysis, because the sample only includes issuer ratings, and not issue ratings (see Section 3.2).

${ }^{8}$ Since U.S.A. is in the group of sovereigns whose ratings were converted to unsolicited, the ratio between sovereign/bank ratings (in our sample 13/74) would be unreasonably inflated in the denominator. With one extra sovereign but a significantly higher number of banks for that one country, any results would be driven by the US case. This is especially problematic because most US banks are rated several notches below the sovereign rating, and hence the sovereign-bank ceiling effect is far more muted for US banks.
} 
The new regulation (Article 10 (5) of the EU Regulation 1060/2009) is compulsory for CRAs, and is therefore applicable to all sovereigns rated by S\&P. For banks operating in the EU to use sovereign ratings for regulatory purposes, the rating solicitation status (of all countries) must be disclosed. ${ }^{9}$ Hence, whenever there is no agreement with a rated government, the CRA must identify the rating as 'unsolicited'. Any government may request to withdraw their ratings, but the CRA may elect to convert the rating to 'unsolicited' status rather than withdraw the rating (S\&P Policy on Withdrawals, Suspensions, Discontinuances and Conversions, December 2014). Further, S\&P may assign unsolicited credit ratings when it believes sufficient market interest exists for the rated entity (S\&P Policy on Assignment of Credit Ratings, May 2014). ${ }^{10}$

There are two possible interpretations of the term 'conversion'. One would be that the ratings were previously solicited or at least S\&P had lines of communication with relevant government agencies. This view is supported by S\&P's choice of the word 'converted' and its withdrawal of issue-level ratings on these sovereigns. A second view would be that the ratings' solicitation status was previously undisclosed and 'converted' refers solely to the public disclosure of being unsolicited. Even if the latter interpretation is true, the setup of this paper is unaffected and remains valid and appropriate.

\footnotetext{
${ }^{9}$ For example, S\&P (2011b) states: 'These actions, in turn, follow new European Union regulations on credit ratings (Article 10(5) of EU Regulation 1060/2009), which address matters relating to the disclosure and presentation of credit ratings, requiring, among other things, that unsolicited credit ratings be identified as such. [.......] We are converting our issuer credit ratings on the six governments to "unsolicited," as we do not have rating agreements with these governments. Nevertheless, Standard \& Poor's will continue to rate these governments and classify the ratings as unsolicited, as we believe that we have access to sufficient public information of reliable quality to support our analysis and ongoing surveillance, and because we believe there is significant market interest in these government ratings.'

${ }^{10}$ All types of ratings (long-term, short-term, local-currency and foreign currency) are subject to the disclosure regulations. The press releases (S\&P, 2011a, b) state: 'Standard \& Poor's is converting its issuer and issue ratings on $[\ldots]$ to "unsolicited",...'. However, the issue ratings are subsequently withdrawn.
} 


\subsection{Bank and rating data}

The sample consists of monthly long-term foreign-currency issuer ratings for banks and sovereigns rated by S\&P between January 2006 and January 2013 ${ }^{11}$ The ratings are observed on the $1^{\text {st }}$ of each month. The scope of sovereign ratings is reflected in Section 3.1. Bank rating data is obtained from both S\&P publications and the Interactive Data Credit Ratings International (CRI) publication. The sample only includes financial institutions because there is a far stronger link between sovereigns and banks than between sovereigns and corporations (see Borensztein et al., 2013; Huang and Shen, 2015). For example, corporates do not use sovereign bonds as collateral and for this reason are not equally affected by sovereign rating fluctuations. Also, for most countries (but not U.S.A.), banks are typically much more likely than corporations to be rated at the sovereign ceiling. The sample is narrowed by matching the credit rating data with the (annual frequency) financial and accounting statistics (see Section 4.1 and Table 3) of publicly listed banks in Europe, Asia-Pacific and Latin America for the period January 2006-January 2013 (sourced from Bankscope). The banks include commercial banks, savings banks, cooperative banks, real estate and mortgage banks, investment banks and other credit institutions.

The sample contains 147 S\&P-rated listed banks in 42 countries. ${ }^{12}$ The studied phenomenon of a regulatory change provides grounds for applying a research design which is based on two groups: treatment and control. The treatment group consists of 13 sovereigns

\footnotetext{
${ }^{11}$ It is standard practice in the literature on the sovereign ceiling effect (e.g. Borensztein et al., 2013; Williams et al., 2013; Alsakka et al., 2014) and on the determinants of bank ratings (e.g. Caporale et al., 2012; Shen et al., 2012; Huang and Shen, 2015) to focus on long-term foreign-currency ratings. In our data sample, the local and foreign currency sovereign ratings are equal for all observations in the 'treatment group' and for the majority of cases in the 'control group'. For the vast majority of bank observations in our data sample, the foreign and local currency ratings are equal.

12 This is the final dataset used in the empirical analysis after some banks and countries exit the initial dataset due to winsorising the accounting data. In winsorising the data, observations which are above the 99.5 percentile and below the 0.5 percentile of the distribution are discarded from the sample.
} 


\subsection{Rating events}

Rating events are identified using a comprehensive credit rating scale (CCR-58 point scale) which includes rating, watch and outlook status. Much recent literature identifies the importance of watch and outlook (e.g. Alsakka et al., 2014; Correa et al. 2014). Rating classes are assigned values from 1 to 58 such that: $\mathrm{AAA}=58, \mathrm{AA}+=55, \ldots, \mathrm{CCC}=7$, CCC$=4, \mathrm{C} / \mathrm{SD} / \mathrm{CC} / \mathrm{D}=1$. For positive watch we add +2 , for positive outlook +1 , whereas for negative outlook and negative watch we subtract 1 and 2, respectively.

Panel A of Table 2 reports the descriptive statistics for the monthly bank credit events. The grand total of monthly observations is 8900 , where 5882 (3018) are observed pre (post) the regulation-induced disclosure of solicitation status (March 2011) ${ }^{13}$ In summary, there are 516 events, consisting of 224 positive and 292 negative actions. The positive (negative) events in the pre-disclosure period amount to $1.75 \%$ (1.79\%) of the grand total of monthly observations (see Column II). After solicitation disclosure rules were implemented by S\&P, positive (negative) events for banks summed to $0.76 \%$ (1.49\%) of the grand total of observations (see Column IV).

Panel B of Table 2 presents the sovereign events. In total, the qualifying sovereigns faced 71 positive and 83 negative rating events. The pre-disclosure phase yields positive and negative events in similar proportions (52 vs. 46 in Column I). They are distributed relatively evenly across the two groups of countries in the sample. In contrast, the post-disclosure phase reveals deteriorating ratings for the group of sovereigns whose ratings converted to

\footnotetext{
${ }^{13}$ On $24^{\text {th }}$ February 2011, S\&P disclosed the unsolicited status on 14 of its sovereign issuers, while Argentina's solicitation status was converted on the $4^{\text {th }}$ April 2011. Because of the monthly data frequency utilised here, whereby ratings are observed on the $1^{\text {st }}$ of each month, March 2011 onwards is the post-treatment period, but this is amended to be May 2011 for Argentina only.
} 
unsolicited, with 2 upgrades and 13 downgrades. Countries which retain solicited ratings after that date have 17 positive versus 24 negative events (see Column III).

The descriptive statistics (Panel A, Column VI) identify a strong ceiling effect which is observed for $97.1 \%$ of sample observations. $78.3 \%$ of bank ratings are lower than the relevant sovereign rating $(\mathrm{B}<\mathrm{S}), 18.8 \%$ of bank ratings equal the sovereign rating $(\mathrm{B}=\mathrm{S})$, and bank ratings pierce the ceiling only in $2.9 \%$ of cases $(B>S)$. Both bank and sovereign ratings are lower after March 2011, on average. In Panel A, the banks' mean rating drops from 37.5 (approx. BBB+) in the pre-disclosure period to 35.4 (approx. BBB) in the post-disclosure period. In Panel B, unsolicited sovereigns' mean numerical ratings decline from 49.8 to 48.8, while solicited sovereigns' mean numerical ratings drop from 38.6 to 37.3. Fig.1 plots annual sovereign ratings against bank ratings per country at the aggregated level. Fig.1 illustrates trends between sovereign and bank ratings for a sample of four countries which switch to unsolicited ratings. Bank ratings in this group rarely exceed those of the sovereign issuer. In the cases of France, Germany and Italy, both sovereign and bank ratings show a substantial decline in the first quarter of 2011 (the time of solicitation status disclosure). ${ }^{14}$

\section{Methodologies}

\subsection{Univariate tests}

We test for differences in the financial profiles of the two groups of banks. To investigate this, we generate t-statistics of means for a number of covariates. These control variables are selected in line with prior research highlighting determinants of bank ratings and are also used in the multivariate analysis. Sovereign ratings are considered as a key factor determining bank ratings (e.g. Shen et al., 2012; Alsakka et al., 2014; Huang and Shen, 2015; Williams et

\footnotetext{
${ }^{14}$ The timing of this effect is not coincidental with the downgrades of countries such as Portugal, Ireland, Greece or Spain, associated with events in the European debt crisis. See Section 6 for formal robustness tests relating to this point. Note that crisis-affected European countries appear in both the treatment and control groups.
} 
al., 2015), while bank rating levels are included to control for the banks' financial conditions and creditworthiness (see Section 2.1 for further details). Variables describing bank size, profitability, asset quality, capital adequacy and liquidity are found to be significant in explaining bank ratings (e.g. Caporale et al., 2012; Shen et al., 2012; Hau et al., 2013. Also, see Section 2.1 for more details). Further, we include the ratio of 'non-interest-income to gross-revenues' to control for the non-traditional intermediation activities of the banks in our sample. This considers whether banks which are oriented towards non-traditional intermediation activities (i.e. commission and fee generating activities, including trading and securitization, investment banking and advisory fees, brokerage commissions, venture capital and non-hedging derivatives activities) are more or less likely to be downgraded compared with banks which are mainly involved in traditional banking activities (deposit taking and lending functions of banks). It is well-documented that the profitability and risk of banks are affected by the extent of non-interest activities of the banks (e.g. Smith et al., 2003; De Jonghe, 2010; Demirgüç-Kunt and Huizinga, 2010).

The summary statistics, abbreviations and definitions of variables used appear in Table 3. Following Poon (2003), when the covariate is an ordinal variable, we apply the WilcoxonMann-Whitney U test. To reduce the frequency of " 0 " in the sample, the lower frequency (annual) data is used in this exercise. The examples of covariates include change in bank ratings, banks' mean ratings and financial variables and ratios. The null hypothesis is rejected for 6 (5) out of 7 covariates in the entire and post-disclosure (pre-disclosure) sample periods. This suggests that banks incorporated in the two groups of sovereigns have distinctive characteristics and are not balanced groups (see Table 4). Banks in the treatment group are characterised by lower returns on equity, lower loan loss reserves and higher total asset-toequity ratio, and their mean bank ratings are higher than those of the control group on 
average. To address the differences in profiles across banks, we conduct a more detailed paired subsample test later in the paper (see multivariate analysis in Section 6.2).

\subsection{Ordered probit model}

To test the hypothesis from Section 2.4, the ordered probit framework is employed. The methodology is widely used in the credit ratings literature because it accounts for the ordinal nature of the dependent variable. Eq. (1) captures the effect of an external and exogenous event (disclosure rules) which feeds through sovereign ratings and to the banks in the considered countries, as follows:

$$
\begin{gathered}
\Delta y_{i, j, t}^{*}=\beta_{1}(\text { Post } * \text { Treatment })_{j, t}+\beta_{2} \Delta \operatorname{Sov} R_{j, s}+\beta_{3} \text { Bank }_{j, t}+\beta_{4} X_{j, t}+\lambda C F * Y F+\varepsilon_{i, j, t} \\
\varepsilon_{i, j, t} \approx N(0,1)
\end{gathered}
$$

$\Delta y *_{i, j, t}$ is an unobserved latent variable connected to the ordinal responses of $\Delta y_{i, j, t}$; change in rating of bank $i$ in country $j$ at month $t$ based on the 58-point CCR scale and taking values of $-3,-2,-1,0,1,2,3$, by the measurement model:

$$
\Delta y_{i, j, t}=\left[\begin{array}{l}
-3 \text { (i.e. bank rating downgrade by } 3 \text { or more CCR points) if } \Delta y{ }_{i, j, t} \leq \alpha 1 \\
-2 \text { (i.e. bank rating downgrade by } 2 \text { CCR points) if } \alpha 1\left\langle\Delta y{ }_{i, j, t} \leq \alpha 2\right. \\
-1 \text { (i.e. bank rating downgrade by } 1 \text { CCR point) if } \alpha 2\left\langle\Delta y *_{i, j, t} \leq \alpha 3\right. \\
0 \text { (i.e. no bank rating change) if } \alpha 3\left\langle\Delta y{ }_{i, j, t} \leq \alpha 4\right. \\
1 \text { (i.e. bank rating upgrade by } 1 \text { CCR point) if } \alpha 4\left\langle\Delta y{ }_{i, j, t} \leq \alpha 5\right. \\
2 \text { (i.e. bank rating upgrade by } 2 \text { CCR points) if } \alpha 5\left\langle\Delta y{ }_{i, j, t} \leq \alpha 6\right. \\
3 \text { (i.e. bank rating upgrade by } 3 \text { or more CCR points) if } \alpha 6\left\langle\Delta y{ }_{i, j, t}\right.
\end{array}\right]
$$

The $(\beta, \lambda)$ parameters of the regression as well as thresholds $(\alpha)$ are estimated using maximum likelihood (ML) estimation and are subject to the constraint $\alpha_{1}<\alpha_{2}<\ldots<\alpha_{\text {J }}$.

Treatment is a dummy variable taking the value of 1 if the country belongs to the treatment group; 0 otherwise.

Post is a dummy variable taking the value of 1 if the observation is from the post-treatment period (March 2011 onwards for all countries, but May 2011 for Argentina); 0 otherwise. 
This main interaction dummy (Post*Treatment) captures the impact of disclosure rules in the regression model. In line with the theoretical explanations of deflated unsolicited ratings (see Section 2.3) and economic intuition, the expected sign of this variable is negative. This is consistent with the notion that bank ratings in countries with unsolicited ratings might face more downgrades (and fewer upgrades) than the banks in the other group due to the rating ceiling effect.

$\Delta \operatorname{Sov}_{j, s}$ represents the change in sovereign CCR by S\&P based on the 3-month window prior to month $\mathrm{t}$ (i.e. $s=$ the $\mathrm{t}-3$ to $\mathrm{t}$ window). It takes the value of $-3,-2,-1,0,1,2$ or 3 . The predicted sign of the coefficient is positive since bank ratings have the tendency to move in the same direction as ratings of their home sovereigns (e.g. Huang and Shen, 2015).

$B a n k R_{j t}$ represents banks' CCR taking values 1-58. This controls for the banking environment. The variable is expected to have a positive sign given that higher bank ratings result in higher probability of bank upgrades and lower probability of bank downgrades and vice versa.

$X_{j t}$ is the set of control variables relating to bank characteristics (see points 1-5 in Table 3). ${ }^{15}$

$C F$ is a full set of country dummy variables.

$Y F$ is a full set of year dummy variables.

Further, we calculate the marginal effects (MEs) to estimate the economic significance of each independent variable on the probability of bank rating changes.

\footnotetext{
15 The correlation matrix (unreported) has been considered, and we find no reason for concern about multicollinearity among the control variables in Eq. (1).
} 


\section{Empirical results}

\subsection{Baseline Model}

Table 5 presents the results of Eq. (1). We discuss Model I initially. To account for unobserved differences in the economic development, industrialisation level or geographical bias concerning sovereigns, Model I includes year-country dummies. Interacting fixed effects became a more common practice in the recent empirical literature (e.g. Jiménez, Ongena, Peydró, and Saurina, 2012). This approach enables us to control for possible omitted variable bias which could result in endogeneity issues (Lemmon and Roberts, 2010). The interaction term accounts for any variation across the time and country spectrum, and controls for differences in the countries' levels of development. The identification of macroeconomic conditions derives entirely from the interactions, in line with Thompson (2011) and Jiménez et al. (2012) who suggest that when fixed effects are used, one needs to drop the macroeconomic covariates from the regression because they become co-linear with the dummy variables.

The coefficient of Post*Treatment is significant with negative sign implying that the conversion of the sovereign status to unsolicited leads to higher probability of bank downgrades and lower probability of upgrades. Hence, ceteris paribus, banks which belong to the treatment group are more likely to be downgraded and less likely to be upgraded compared with banks not in the treatment group. The marginal effects analysis suggests that such banks are $1.85 \%, 0.93 \%$ and $0.79 \%$ more likely to be downgraded by 1,2 and $\geq 3$ CCR points respectively (see Table 6). The effect of the treatment dummy represents a strong marginal effect in comparison with the 3.28\% (2.73\%) of negative bank (sovereign) rating events observed in the entire data sample (see Table 2, Panel A (B), Column VI).

The estimated coefficients of $\Delta S o v R$ and BankR are significant and economically relevant. The sign on both coefficients is in line with expectations and remains robust to inclusion of 


\footnotetext{
${ }^{16}$ As robustness tests, we have re-estimated Eq. (1) using (i) a sub-sample excluding countries with a single bank in the sample, and (ii) a sub-sample excluding Japan (which has the highest number of rated banks and therefore might be overrepresented in the sample). The (unreported) results show that Post* Treatment remains negative and significant throughout all specifications with these differing sub-samples.
} 
Demirgüç-Kunt and Huizinga (2010) also show that banks with higher levels of non-interest income engender a materially higher bank risk.

\subsection{Various fixed effect models}

Model I of Eq. (1) accounts for observed time-varying bank specifics (e.g. profitability measures, size, credit rating) and identifies the impact of observed and unobserved changes in macro-economic conditions through the year-country interaction dummy. However, the model could still be considered incomplete because it does not control for unobservable timevariant bank heterogeneity (e.g. banks' risks, quality and investment prospects, and access to finance) (see Petersen and Rajan, 1994). To address this issue, Models II, III and IV in Table 5 present the estimation of Eq. (1) using various fixed effect models and clustering options applied to the baseline Model I (following an approach similar to Jiménez et al., 2012).

In Model II, we cluster on the bank level to test for firm effects. The inclusion of bank controls in the model addresses observable differences in banks' profiles affecting rating changes but does not handle the unobserved effects which could be driving these differences and the dependent variable itself. Clustering on the bank level in the regression helps to correct for these omitted and possibly unobserved effects and confirms the randomisation of the treatment effect. The results are consistent with those of Model I.

Model III tests whether any time effect is present, using month fixed effects applied to the baseline Model I. Monthly fixed effects apprehend variations in macroeconomic conditions such as shocks to the economy, inflation or interest rates. The coefficient on the treatment dummy remains strongly statistically significant with the expected negative sign. We applied clustering on the same level as the fixed effects (monthly) and find that the time effect is constant. $^{17}$

\footnotetext{
${ }^{17}$ The test following Petersen (2009) (not reported here) added month clustering to the month fixed effects. No substantial differences were observed among the standard errors.
} 
In Model IV, we control for correlation between time and cross-section dimensions simultaneously (Faulkender and Petersen, 2006; Thompson, 2011). In addition to monthly dummies, from Model III, we cluster on the bank level. Monthly dummies eliminate the correlations between observations occurring at the same time intervals (time effects). This results in a 'pure' firm effect with unbiased standard errors (Petersen, 2009). We also include bank fixed effects. The coefficient on the treatment dummy in Model IV increases further (0.695). The negative sign of the coefficient once more confirms the robustness of our results and supports the underlying hypothesis. MEs suggest that banks in the treatment group are $1.73 \%, 0.74 \%$ and $0.47 \%$ more likely to be downgraded by 1,2 and $\geq 3$ CCR points than banks in the other group (Table 6, Panel D). In terms of goodness of fit, the model improves compared to earlier versions (pseudo $\mathrm{R}^{2}$ of 0.214 ). The explanatory power also remains the highest (log likelihood of -2246), which suggests that this is the preferred model.

In brief, the results show that the effect of sovereign solicitation conversion is negative and statistically significant for those banks belonging to the group of sovereigns whose ratings are disclosed as unsolicited. Results remain robust across various specifications.

\section{Robustness tests}

\subsection{Falsification tests}

To link the impact of solicitation disclosure rules to the bank rating changes, we focus on the differences arising between the treatment and control groups. In this setting, one needs to rule out the possibility that any other events coincide with the adoption of the disclosure rules. This relates to the notion that changes (due to disclosure rules) should only be observed across banks incorporated in the treated countries and not for the opposite group or at a different time than the first quarter of 2011. To confirm that no undetected issues interfere with the results, we run a set of placebo regressions focusing on: (a) time spectrum variations 


\footnotetext{
${ }^{18}$ In model IV, the leads are insignificant at 1, 2 and 3 months prior to the authentic event date (see Table 7).

${ }^{19}$ The random number generator in STATA assigns a placebo to a subset of banks from the control group. The placebo equals one when the (randomly assigned) bank in question belongs to the control group and if the observation is from the post-treatment period. The results of three trials are presented in Panel A of Table 8.

${ }^{20}$ The generator randomly selects a fraction of sovereigns belonging to the control group and assigns the placebo effect to all banks which operate in those sovereigns. Subsequently, replicated regressions with the placebo effect follow. As in the first instance, the treatment group is excluded from the sample. The results of three consecutive trials are presented in Panel B of Table 8.

${ }^{21}$ These include: In(Assets), Leverage, LLR/GL (described in Table 3); SOV20SCALE (BANK20SCALE): sovereign (bank) credit rating expressed in 20-notch scale; MEANCPI: mean CPI (Consumer Price Index) value per sovereign. Inflation is measured as average annual consumer price inflation growth on a year-over-year
} 
to the treatment. According to Rosenbaum and Rubin (1985, p.41) the "propensity score is the conditional probability of assignment to a particular treatment given a vector of observed covariates". For the conditional mean independence assumption to hold, the outcome variable must be independent of treatment bounded by the propensity score (Smith and Todd, 2005). Additionally, all variables which affect both the fact that the treatment is observed and the outcome of that treatment need to be included in the propensity score.

To the best of our knowledge, there is no literature examining the economics (determinants) of the sovereign solicitation status. The observable characteristics which could potentially persuade a government to seek a solicited rating (or remain unsolicited) might be triggered by the state of the national economy represented by inflation, among other factors. Nonetheless, there is a possibility that the treatment has impact on the factors which are selected to explain its phenomenon and therefore we fix them over time. We test the balancing assumption that the means of covariates in the opposing groups do not differ from each other after the matching (Rubin and Thomas, 1996). The results (presented in Table 9) confirm that all the covariates are insignificant in the matched cases. After the matching, there is significant reduction in bias. ${ }^{22}$ On average, covariate bias decreases by 90 per cent.

Subsequently, we re-estimate the ordered probit model where the bank rating change is a function of the propensity score, treatment dummy and previously used fixed effects (i.e. Models I-IV, Table 5). All tested models generate negative coefficients for the treatment dummy. The magnitude of the effect in Model I and II is akin to that in the unmatched sample. The regression approach confirms that the estimates used prior to the matching

\footnotetext{
basis for the previous three years in per cent terms to correct for procyclicality. This method helps in eliminating the business cycle effect. MEANCPI is fixed over time. CPI data is obtained from DataStream.

${ }^{22}$ To confirm that the control group is sufficiently similar to the treatment group, it is required that the maximum difference between the propensity score of the two groups (caliper) does not exceed 1\% in absolute value. The reported $p$-value of the difference in mean P-scores ranges between 0.113 and 0.821 .
} 
exercise robustly represented the economic significance of the effect of the solicitation disclosure on the studied sample. ${ }^{23}$

\subsection{Endogeneity issues}

For the estimation of unbiased and consistent parameters, which allow a reliable inference, the possible sources of endogeneity need to be considered and minimised. We are interested to know whether the disclosure events were exogeneous with respect to bank rating changes. A potential concern could be that the negative rating events among banks (and sovereigns) in the pre-disclosure period were a reason for regulators to press for transparency on unsolicited ratings. The concerns which led to regulatory changes in our sample period could be justified if there were signs of the anticipated decline in the creditworthiness of banks and sovereigns. The descriptive statistics in Table 2 invalidate this explanation given that bank upgrades outweighed downgrades in the period prior to introduction of the disclosure rules.

Economic rationale further disqualifies the possibility that S\&P converted the solicitation status on several sovereigns due to operations of banks incorporated in these countries. It is implausible that the bank rating changes would in any way affect the decision of the CRA since the ceiling effect is observed in 97.1 per cent of cases (see Column VI of Table 2). It is very rare to find bank rating actions which precede their home sovereign actions within a short time window. Similarly to Alsakka et al. (2014), we find no evidence whatsoever of a bank-to-sovereign rating channel. The motivation of the new disclosure rules was linked to better transparency, disclosure and presentation of credit ratings rather than anticipated declines in economic activity. To further reduce potential endogeneity concerns, we employ a propensity score matching procedure to identify statistically indistinguishable subsamples

\footnotetext{
${ }^{23}$ A final robustness test estimates Eq. (1) using Ordinary Least Squares which takes the form of a difference-indifference (DID) estimation. Although the discrete nature of the dependent variable is best estimated with the ordered probit model, it became recent practice to use the OLS as an alternative method (e.g. Becker and Milbourn, 2011; Van Roy, 2013). The economic inference of estimated Eq. (1) does not change and the treatment effect remains negative and significant throughout all specifications.
} 


\section{Conclusions}

The regulatory oversight of CRAs in Europe underwent significant reform with the introduction of the CRA I Regulation in September 2009 and assigning to ESMA the function of supervising and certifying CRAs across the EU from July 2011. In early 2011, as a consequence of Article 10 (5) of EU Regulation 1060/2009, S\&P converted the solicitation status on several sovereigns to unsolicited. This paper considers whether the regulatory changes negatively affected bank ratings in countries whose sovereign ratings were converted to unsolicited. The dataset consists of S\&P ratings of 147 listed banks from 42 sovereigns in Europe, Asia-Pacific and Latin America for January 2006-January 2013.

We find that banks incorporated in states whose ratings converted to unsolicited status demonstrate higher probabilities of rating downgrades and lower probabilities of rating upgrades in comparison to other banks. The results also suggest that sovereign rating downgrades adversely influence bank ratings through the rating channel. Among the existing theories of deflated unsolicited ratings, the concept of strategic conservatism is most plausible in explaining these findings. Specifically, a reduced information flow from issuers under the 'unsolicited' status could justify lower S\&P ratings. The results are statistically robust and economically relevant. Several specifications with a number of fixed effects and clustering options are applied. The sign and significance of the effect remains unchanged. We apply several falsification tests to rule out the possibility that any other events coincide with the adoption of the regulation or that selection bias is present.

These findings fill a clear void in the literature by examining the effect of sovereign solicitation status on the banking sector. The synergy of three overlapping themes of research 
reveals a phenomenon which has not been tackled by earlier theoretical nor empirical papers. The study contributes to research on unsolicited credit ratings by uncovering the significance of the solicitation status of sovereigns and its role in the domestic markets. In addition, the paper supplements recent empirical efforts examining the rating channel between sovereigns and banks. We find that the sovereign solicitation status matters for market participants in each country due to the rating ceiling effect. Last but not least, the paper incorporates the new EU regulatory changes imposed on CRAs and is one of the first to report its impact on relevant markets.

CRAs' use of the sovereign-bank rating ceiling has surprisingly been rather neglected by researchers until quite recently (Borensztein et al., 2013; Williams et al., 2013; Alsakka et al., 2014; Huang and Shen, 2015). It has also seemingly fallen under the radar of regulations to some extent. Similarly, rating solicitation has attracted wide attention in the corporate sphere (e.g. Poon et al., 2009; Bannier et al., 2010), but no attention whatsoever in sovereign rating research literature. In designing new disclosure requirements for CRAs in 2009-11 (with good intentions), EU regulators failed to connect the issues of unsolicited rating and sovereign-bank linkages. It is somewhat surprising that any consultation process failed to highlight this issue, but the lack of closely relevant academic research could be a contributing factor. This paper fills this void and identifies a clear case of an unintended consequence of regulatory disclosure. Future regulatory reforms need to be undertaken with caution as they might further aggravate the conditions for debt issuers.

The findings are also of importance to CRAs and market participants. There are obvious implications of how the sovereign rating methods influence the functioning of financial markets. Governments need to appreciate the consequences of their decision-making with regard to rating solicitations. 


\section{Acknowledgements}

We are indebted to the Editors and two anonymous referees for their constructive suggestions. We are very grateful for comments from Philip Molyneux, John Wilson and other participants at the 2015 Contemporary Issues in Banking Conference (at the University of St Andrews). We are also grateful to seminar participants at EFMA 2015 (Amsterdam), at Heriot-Watt University and the University of Manchester.

\section{References}

Alsakka, R., ap Gwilym, O., Vu, N.T. (2014). The sovereign-bank rating channel and rating agencies' downgrades during the European debt crisis. Journal of International Money and Finance, 49(B), 235-257.

Arezki, R., Candelon, B., Sy, A.N.R. (2011). Sovereign rating news and financial markets spillovers: evidence from the European debt crisis. IMF Working Paper No. 11/68, 1-27.

Bank for International Settlements (BIS) (2011). The impact of sovereign credit risk on bank funding conditions. Committee on the Global Financial System, CGFS Papers No 43.

Bannier, C.E., Behr, P., Güttler, A. (2010). Rating opaque borrowers: why are unsolicited ratings lower? Review of Finance, 14(2), 263-294.

Bar-Isaac, H., Shapiro, J. (2013). Ratings quality over the business cycle. Journal of Financial Economics, 108(1), 62-78.

Becker, B., Milbourn, T. (2011). How did increased competition affect credit ratings? Journal of Financial Economics, 101(3), 493-514.

Borensztein, E., Cowan, K., Valenzuela. P. (2013). Sovereign ceiling lite? The impact of sovereign ratings on corporate ratings in emerging market economies. Journal of Banking and Finance, 37(11), 4014-4024.

Caporale, G., Matousek, R., Stewart, C. (2012). Ratings assignments: Lessons from international banks. Journal of International Money and Finance, 31(6), 593-1606.

Caselli, S., Gandolfi, G., Soana, M. (2014). The impact of sovereign rating news on European banks. European Financial Management, 22(1), 2016, 142-167.

Correa, R., Lee, K., Sapriza, H., Suarez, G.A. (2014). Sovereign credit risk, banks' government support, and bank stock returns around the world. Journal of Money, Credit and Banking, 46(1), 93-121.

De Bruyckere, V., Gerhardt, M., Schepens, G., Vennet, R.V. (2013). Bank/sovereign risk spillovers in the European debt crisis. Journal of Banking and Finance, 37(12), 47934809. 
De Jonghe, O. (2010). Back to the basics in banking? A micro-analysis of banking system stability. Journal of Financial Intermediation 19, 387-417.

Demirgüç-Kunt, A., Huizinga, H. (2010). Bank activity and funding strategies: The impact on risk and returns. Journal of Financial Economics 98 (3), 626-650.

Duff, A., Einig, S. (2009). Credit ratings quality: the perceptions of market participants and other interested parties. British Accounting Review, 41(3), 141-153.

Faulkender, M., Petersen, M. (2006). Does the source of capital affect capital structure? Review of Financial Studies, 19(1), 45-79.

Fitch Ratings, (2012). Country ceilings effective from 13 August 2012 - 9 August 2013. Cross-Sector Criteria Report, Sovereigns Global.

Fulghieri, P., Strobl, G., Xia, H. (2014). The economics of solicited and unsolicited credit ratings. Review of Financial Studies, 27(2), 484-518.

Hau, H., Langfield, S., Marques-Ibanez, D. (2013). Bank ratings: what determines their quality? Economic Policy, April, 289-333.

Huang, Y., Shen, C. (2015). The sovereign effect on bank credit ratings. Journal of Financial Services Research, 47(3), 341-379.

Jiménez, G., Ongena, S., Peydró, J., Saurina, J. (2012). Credit supply and monetary policy: identifying the bank balance-sheet channel with loan applications. American Economic Review, 102(5), 2301-2326.

Jorion, P., Liu, Z., Shi, C. (2005). Informational effects of regulation FD: evidence from rating agencies. Journal of Financial Economics, 76(2), 309-330.

Lemmon, M., Roberts, M.R. (2010). The response of corporate financing and investment to changes in the supply of credit. Journal of Financial and Quantitative Analysis, 45(3), 555-87.

Li, J., Shin, Y.S., Moore, W.T. (2006). Reactions of Japanese markets to changes in credit ratings by global and local agencies. Journal of Banking and Finance, 30(3), 1007-1021.

Opp, C.C., Opp, M.M., Harris, M. (2013). Rating agencies in the face of regulation. Journal of Financial Economics, 108(1), 46-61.

Petersen, M., Rajan, R.G. (1994). The benefits of lending relationships: evidence from small business data. Journal of Finance, 49(1), 3-37.

Petersen, M. (2009). Estimating standard errors in finance panel data sets: comparing approaches. Review of Financial Studies, 22(1), 435-480.

Poon, W. (2003). Are unsolicited credit ratings biased downward? Journal of Banking and Finance, 27(4), 593-614.

Poon, W., Evans, D. (2013). Regulation Fair Disclosure's effect on the information content of bond rating changes. European Financial Management, 19(4), 775-800. 
Poon, W., Lee, J., Gup, B.E. (2009). Do solicitations matter in bank credit ratings? Results from a study of 72 countries. Journal of Money, Credit and Banking, 41(2-3), 285-314.

Ramakrishnan, R.T.S., Thakor, A.V. (1984). Information reliability and a theory of financial intermediation. Review of Economic Studies, 51(3), 415-432.

Rosenbaum, P.R., Rubin, D.B. (1985). Constructing a control group using multivariate matched sampling methods that incorporate the propensity score. The American Statistician, 39(1), 33-38.

Rubin, D.B., Thomas, N. (1996). Matching using estimated propensity scores: relating theory to practice. Biometrics, 52(1), 249-264.

Shen, C., Huang, Y., Hasan, I. (2012). Asymmetric benchmarking in bank credit rating. Journal of International Financial Markets, Institutions and Money, 22(1), 171-193.

Smith, J.A., Todd, P.E. (2005). Does matching overcome LaLonde's critique of nonexperimental estimators? Journal of Econometrics, 125, 305-353.

Smith, R., Staikouras, C., Wood, G. (2003). Non-interest income and total income stability. Bank of England Working Paper no. 198.

S\&P (2011a). Ratings On Seven European Sovereigns and The European Central Bank Converted To Unsolicited Ratings. February 24, 2011.

S\&P (2011b). Ratings On Six Asia-Pacific Sovereigns Converted To Unsolicited Ratings. February 24, 2011.

S\&P (2011c). Ratings On The U.S. Government Converted To Unsolicited Ratings. February 24, 2011.

S\&P Policy on Withdrawals, Suspensions, Discontinuances and Conversions, December. 2014.

S\&P Policy on Assignment of Credit Ratings, May 2014.

Sy, A.N.R. (2009). The systemic regulation of credit rating agencies and rated markets. World Economics, 10, 69-108.

Thompson, S.B. (2011). Simple formulas for standard errors that cluster by both firm and time. Journal of Financial Economics, 99, 1-10.

Van Roy, P. (2013). Is there a difference between solicited and unsolicited bank ratings and if so, why? Journal of Financial Services Research, 44(1), 53-86.

Williams, G., Alsakka, R., ap Gwilym O. (2013). The impact of sovereign rating actions on bank ratings in emerging markets. Journal of Banking and Finance, 37(2), 563-577.

Williams, G., Alsakka, R., ap Gwilym O. (2015). Does sovereign creditworthiness affect bank valuations in emerging markets? Journal of International Financial Markets, Institutions \& Money, 36, 113-129.

Wyman, O. (2011). The state of European bank funding. November. 


\section{Table 1}

\section{Treatment group}

\section{Argentina}

Banco de Galicia y Buenos Aires SA

Banco Hipotecario SA

Banco Patagonia SA

\section{Australia}

Australia and New Zealand Banking

Bank of Queensland Limited

Bendigo and Adelaide Bank Limited

Commonwealth Bank of Australia

Macquarie Group Ltd

MyState Bank Limited

National Australia Bank Limited

\section{Cambodia}

\section{ACLEDA Bank PLC}

\section{France}

BNP Paribas

Société Générale

\section{Germany}

Deutsche Bank AG

Deutsche Postbank AG

India

AXIS Bank Limited

Bank of Baroda

Bank of India

Canara Bank

HDFC Bank Ltd

ICICI Bank Limited

Indian Bank

Indian Overseas Bank

Italy

Banca Carige SpA

Banca Monte dei Paschi di Siena SpABanca Popolare dell'Emilia Romagna Banca Popolare di Milano SCaRL

Credito Bergamasco

Credito Emiliano SpA-CREDEM

Intesa Sanpaolo

Mediobanca SpA

Netherlands

ABN AMRO Bank NV

ING Groep NV

Singapore

Oversea-Chinese Banking Corporation

Switzerland

Credit Suisse Group AG

UBS AG

Vontobel Holding AG-Vontobel Group

Taiwan

Chang Hwa Commercial Bank Ltd.

China Development Financial Holding

First Financial Holding Company

Fubon Financial Holding Co Ltd

Sinopac Financial Holdings 
Table 1 - Continued.

Treatment group
Japan
77 Bank (The)
Aozora Bank Ltd
Bank of Kyoto
Chiba Bank Ltd.
Chugoku Bank, Ltd. (The)
Credit Saison Co Ltd
Daishi Bank Ltd (The)
Daiwa Securities Group Inc
Gunma Bank Ltd. (The)
Hachijuni Bank
Higo Bank (The)
Hiroshima Bank Ltd
Hitachi Capital Corporation

Japan

United Kingdom

Barclays Plc

HSBC Holdings Plc

Lloyds Banking Group Plc

Royal Bank of Scotland Group Plc

Schroders Plc

Standard Chartered Plc
Hokkoku Bank Ltd. (The)

Hyakugo Bank Ltd.

Joyo Bank Ltd.

Juroku Bank Ltd. (The)

Kagoshima Bank Ltd. (The)

Keiyo Bank, Ltd. (The)

Mitsubishi UFJ Financial Group Inc.

Mizuho Financial Group

Nomura Holdings Inc

Orix Corporation

Shinkin Central Bank

Shinsei Bank Limited

Shizuoka Bank

Notes: This table lists sovereigns and S\&P-rated banks incorporated in these countries used for our analysis (January 2006 to January 2013). The treatment group consists of sovereigns whose solicitation status was converted to unsolicited whereas the control group consists of sovereigns whose S\&P ratings remained solicited throughout the sample period. 
Table 2

Descriptive statistics of the data sample

\begin{tabular}{|c|c|c|c|c|c|c|c|}
\hline \multirow{3}{*}{$\begin{array}{l}\text { Countries } \\
\text { No. of listed S\&P-rated banks } \\
\text { Column Number }\end{array}$} & \multirow{2}{*}{$\begin{array}{c}42 \\
147\end{array}$} & \multicolumn{3}{|c|}{ No. of "unsolicited sovereigns" } & \multicolumn{3}{|c|}{13} \\
\hline & & \multicolumn{3}{|c|}{ No. of "solicited sovereigns" } & \multicolumn{3}{|c|}{29} \\
\hline & I & II & III & IV & & $\mathbf{V}$ & VI \\
\hline & No. & $\begin{array}{l}\text { \% of } \\
\text { Grand total }\end{array}$ & No. & $\begin{array}{l}\text { \% of } \\
\text { Grand to }\end{array}$ & & No. & $\begin{array}{l}\text { \% of } \\
\text { Grand total }\end{array}$ \\
\hline Panel A- Banks & \multicolumn{2}{|c|}{ Pre-disclosure } & \multicolumn{2}{|c|}{ Post-disclosure } & \multicolumn{3}{|c|}{ Grand total } \\
\hline Observations & 5882 & & 3018 & & & 8900 & \\
\hline Average numerical rating & 37.54 & & 35.36 & & & 36.80 & \\
\hline Upgrade by 1 CCR point & 91 & $1.02 \%$ & 25 & $0.28 \%$ & & 116 & $1.30 \%$ \\
\hline Upgrade by 2 CCR points & 46 & $0.52 \%$ & 21 & $0.24 \%$ & & 67 & $0.75 \%$ \\
\hline Upgrade by $>2$ CCR points & 19 & $0.21 \%$ & 22 & $0.25 \%$ & & 41 & $0.46 \%$ \\
\hline Downgrade by 1 CCR point & 88 & $0.99 \%$ & 51 & $0.57 \%$ & & 139 & $1.56 \%$ \\
\hline Downgrade by 2 CCR points & 37 & $0.42 \%$ & 34 & $0.38 \%$ & & 71 & $0.80 \%$ \\
\hline Downgrade by $>2$ CCR points & 34 & $0.38 \%$ & 48 & $0.54 \%$ & & 82 & $0.92 \%$ \\
\hline Positive events & 156 & $1.75 \%$ & 68 & $0.76 \%$ & & 224 & $2.52 \%$ \\
\hline Negative events & 159 & $1.79 \%$ & 133 & $1.49 \%$ & & 292 & $3.28 \%$ \\
\hline $\mathrm{B}>\mathrm{S}$ & 228 & $2.56 \%$ & 34 & $0.38 \%$ & & 262 & $2.94 \%$ \\
\hline $\mathrm{B}=\mathrm{S}$ & 1031 & $11.58 \%$ & 641 & $7.20 \%$ & & 1672 & $18.79 \%$ \\
\hline $\mathrm{B}<\mathrm{S}$ & 4623 & $51.94 \%$ & 2343 & $26.33 \%$ & & 6966 & $78.27 \%$ \\
\hline Panel B- Sovereigns & \multicolumn{2}{|c|}{ Pre-disclosure } & \multicolumn{2}{|c|}{ Post-disclosure } & \multicolumn{3}{|c|}{ Grand total } \\
\hline \multicolumn{8}{|l|}{ "Unsolicited" sovereigns } \\
\hline Average numerical rating & 49.81 & & 48.82 & & 49 & & \\
\hline Upgrade by 1 CCR point & 4 & $0.13 \%$ & 1 & $0.03 \%$ & 5 & & $0.16 \%$ \\
\hline Upgrade by 2 CCR points & 2 & $0.07 \%$ & 1 & $0.03 \%$ & 3 & & $0.10 \%$ \\
\hline Upgrade by $>2$ CCR points & 1 & $0.03 \%$ & 0 & $0.00 \%$ & 1 & & $0.03 \%$ \\
\hline Downgrade by 1 CCR point & 4 & $0.13 \%$ & 6 & $0.20 \%$ & 10 & & $0.33 \%$ \\
\hline Downgrade by 2 CCR points & 3 & $0.10 \%$ & 4 & $0.13 \%$ & 7 & & $0.23 \%$ \\
\hline Downgrade by $>2$ CCR points & 1 & $0.03 \%$ & 3 & $0.10 \%$ & 4 & & $0.13 \%$ \\
\hline Positive events & 7 & $0.23 \%$ & 2 & $0.07 \%$ & 9 & & $0.30 \%$ \\
\hline Negative events & 8 & $0.26 \%$ & 13 & $0.43 \%$ & 21 & & $0.69 \%$ \\
\hline \multicolumn{8}{|l|}{ "Solicited" sovereigns } \\
\hline Average numerical rating & 38.63 & & 37.31 & & 38 & & \\
\hline Upgrade by 1 CCR point & 20 & $0.66 \%$ & 8 & $0.26 \%$ & 28 & & $0.92 \%$ \\
\hline Upgrade by 2 CCR points & 12 & $0.39 \%$ & 5 & $0.16 \%$ & 17 & & $0.56 \%$ \\
\hline Upgrade by >2 CCR points & 13 & $0.43 \%$ & 4 & $0.13 \%$ & 17 & & $0.56 \%$ \\
\hline Downgrade by 1 CCR point & 16 & $0.53 \%$ & 7 & $0.23 \%$ & 23 & & $0.76 \%$ \\
\hline Downgrade by 2 CCR points & 4 & $0.13 \%$ & 5 & $0.16 \%$ & 9 & & $0.30 \%$ \\
\hline Downgrade by $>2$ CCR points & 18 & $0.59 \%$ & 12 & $0.39 \%$ & 30 & & $0.99 \%$ \\
\hline Positive events & 45 & $1.48 \%$ & 17 & $0.56 \%$ & 62 & & $2.04 \%$ \\
\hline Negative events & 38 & $1.25 \%$ & 24 & $0.79 \%$ & 62 & & $2.04 \%$ \\
\hline
\end{tabular}

Notes: This table presents summary statistics for the credit rating dataset, which includes monthly bank (Panel A) and sovereign ratings (Panel B) by S\&P including outlook and watch for 147 banks from 42 countries for pre- disclosure (January 2006 to February 2011) and post-disclosure (March 2011 to January 2013) periods. $\mathrm{B}=\mathrm{S}, \mathrm{B}<\mathrm{S}$, and $\mathrm{B}>\mathrm{S}$ identify: banks rated the same as the sovereign, banks rated lower than the sovereign, and banks rated better than the sovereign, respectively. "Unsolicited" refers to sovereigns whose S\&P rating status converted from solicited to unsolicited in 2011. Columns II, IV and VI refer to the percentage of the grand total of observations in Column V. 


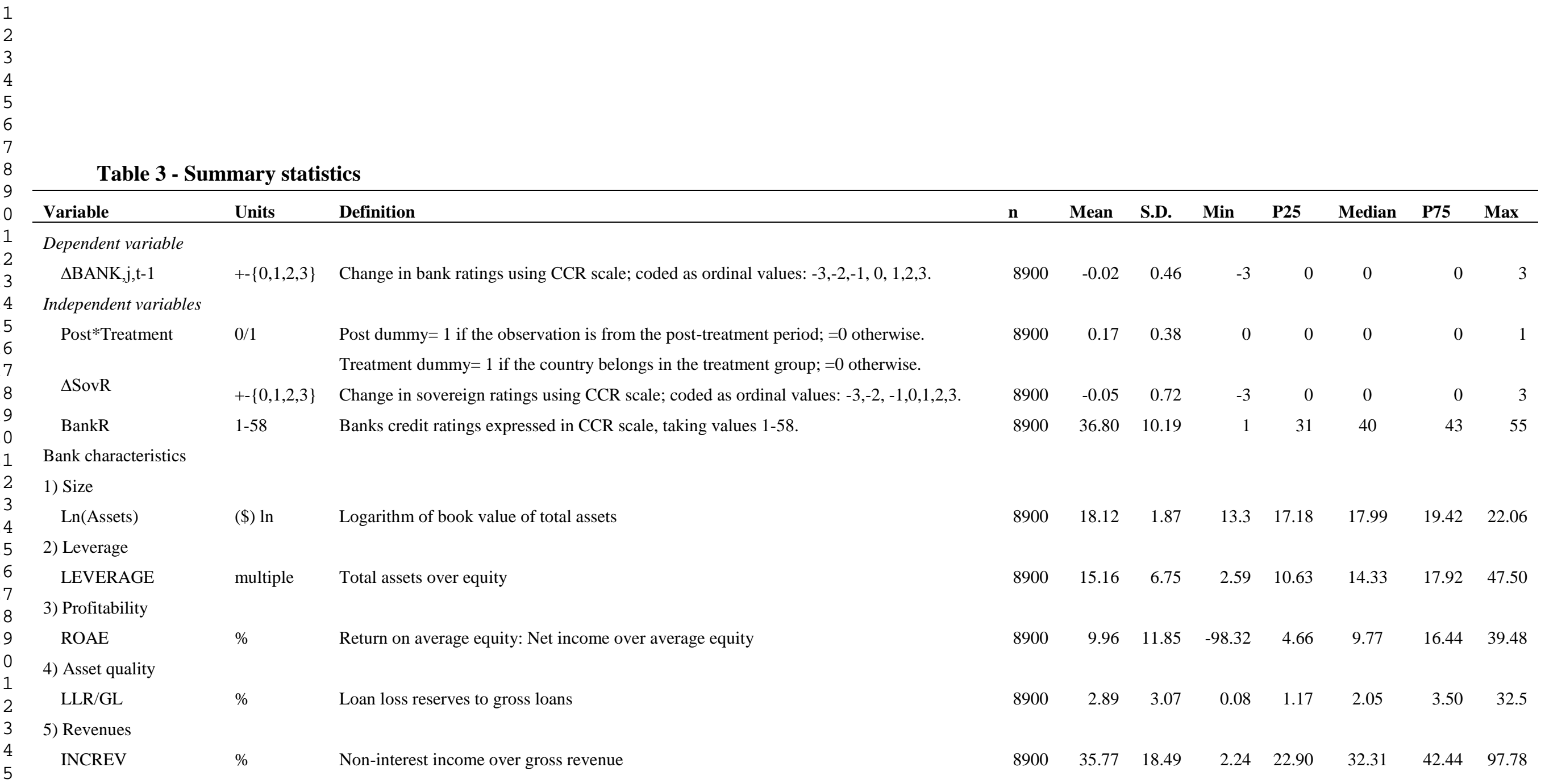

Notes: This table presents summary statistics, abbreviations and definitions of variables used in the univariate and multivariate analysis for monthly observations of the sample of 147 banks originating from 42 countries for the period January 2006- January 2013. "n" is the number of observations, "S.D." is standard deviation. The sample represents a balanced panel data with regards to the dependent variable and main explanatory variables. 


\begin{tabular}{|c|c|c|c|c|c|c|}
\hline Variable & $\begin{array}{l}\text { No. of } \\
\text { observations }\end{array}$ & Sample period & $\begin{array}{l}\text { Mean } \\
\text { (control) }\end{array}$ & $\begin{array}{l}\text { Mean } \\
\text { (treatment) }\end{array}$ & Difference & $p$-value \\
\hline$\Delta \mathbf{B A N K}$ & 886 & Whole & 0 & -0.128 & 0.128 & $0.085^{*}$ \\
\hline$\triangle \mathbf{B A N K}$ & 486 & pre-treatment & -0.076 & 0.032 & -0.108 & 0.539 \\
\hline$\triangle \mathbf{B A N K}$ & 400 & post-treatment & 0.091 & -0.328 & 0.419 & $0.002 * * *$ \\
\hline BankR & 886 & whole & 32.976 & 40.039 & -7.062 & $0.000 * * *$ \\
\hline BankR & 486 & pre-treatment & 33.568 & 41.158 & -7.590 & $0.000 * * *$ \\
\hline BankR & 400 & post-treatment & 32.281 & 38.636 & -6.355 & $0.000 * * *$ \\
\hline $\ln$ (Assets) & 886 & whole & 17.447 & 18.740 & -1.292 & $0.000 * * *$ \\
\hline $\ln$ (Assets) & 486 & pre-treatment & 17.395 & 18.760 & -1.364 & $0.000 * * *$ \\
\hline $\ln$ (Assets) & 400 & post-treatment & 17.508 & 18.714 & -1.206 & $0.000 * * *$ \\
\hline LEVERAGE & 886 & whole & 12.717 & 17.133 & -4.415 & $0.000 * * *$ \\
\hline LEVERAGE & 486 & pre-treatment & 13.313 & 17.798 & -4.485 & $0.000 * * *$ \\
\hline LEVERAGE & 400 & post-treatment & 12.018 & 16.299 & -4.281 & $0.000 * * *$ \\
\hline ROAE & 886 & whole & 12.494 & 7.578 & 4.915 & $0.000 * * *$ \\
\hline ROAE & 486 & pre-treatment & 13.602 & 8.425 & 5.177 & $0.000 * * *$ \\
\hline ROAE & 400 & post-treatment & 11.191 & 6.517 & 4.674 & $0.000 * * *$ \\
\hline LLR/GL & 886 & whole & 3.611 & 2.384 & 1.226 & $0.000^{* * *}$ \\
\hline LLR/GL & 486 & pre-treatment & 3.063 & 2.247 & 0.815 & $0.008 * * *$ \\
\hline LLR/GL & 400 & post-treatment & 4.256 & 2.556 & 1.700 & $0.001 * * *$ \\
\hline INCREV & 886 & whole & 33.674 & 38.007 & -4.332 & 0.137 \\
\hline INCREV & 486 & pre-treatment & 34.585 & 37.539 & -2.953 & 0.616 \\
\hline INCREV & 400 & post-treatment & 32.603 & 38.594 & -5.991 & 0.085 \\
\hline
\end{tabular}

Notes: The table presents results of the Wilcoxon-Mann-Whitney U test where differences between financial profiles of sovereigns which converted (treatment) and did not convert (control) the solicitation status are tested with use of seven covariates for the pre-treatment (Jan 2006 to Feb 2011) and the entire period (Jan 2006 to Jan 2013) using yearly data (see Section 4.1). See Table 3 for variable definitions.

Significance levels are: $* * * p<1 \%, * * p<5 \%, * p<10 \%$. 
Table 5

Ordered probit model results

Model

(I)

(II)

(III)

(IV)

variables

\begin{tabular}{|c|c|c|c|c|}
\hline Post*Treatment & $-0.5998 * * *$ & $-0.5998 * * *$ & $-0.4536 * * *$ & $-0.6949 * * *$ \\
\hline \multirow[b]{2}{*}{$\Delta$ SovR } & $(-4.87)$ & $(-4.18)$ & $(-2.66)$ & $(-2.73)$ \\
\hline & $0.3989 * * *$ & $0.3989 * * *$ & $0.3945 * * *$ & $0.3925 * * *$ \\
\hline \multirow[b]{2}{*}{ BankR } & $(12.81)$ & (11.83) & $(11.66)$ & $(10.50)$ \\
\hline & $0.0488 * * *$ & $0.0488 * * *$ & $0.0357 * * *$ & $0.1344^{* * *}$ \\
\hline \multirow[b]{2}{*}{$\ln$ (Assets) } & $(6.30)$ & $(6.01)$ & (4.99) & (5.38) \\
\hline & $-0.1667 * * *$ & $-0.1667 * * *$ & $-0.1461^{* * *}$ & $-0.6943 * * *$ \\
\hline \multirow[b]{2}{*}{ LEVERAGE } & $(-5.46)$ & $(-4.62)$ & $(-4.83)$ & $(-5.40)$ \\
\hline & 0.0047 & 0.0047 & -0.0043 & $-0.0234 *$ \\
\hline \multirow{3}{*}{ ROAE } & $(0.74)$ & $(0.81)$ & $(-0.74)$ & $(-1.75)$ \\
\hline & -0.0008 & -0.0008 & -0.0022 & $-0.0108^{* *}$ \\
\hline & $(-0.20)$ & $(-0.25)$ & $(-0.65)$ & $(-2.45)$ \\
\hline LLR/GL & -0.0007 & -0.0007 & 0.0053 & -0.0159 \\
\hline \multirow{3}{*}{ INCREV } & $(-0.07)$ & $(-0.09)$ & $(0.55)$ & $(-0.75)$ \\
\hline & $0.0026^{*}$ & $0.0026 * *$ & 0.0011 & 0.0027 \\
\hline & (1.65) & $(2.42)$ & $(0.67)$ & $(0.47)$ \\
\hline Observations & 8900 & 8900 & 8900 & 8900 \\
\hline Log likelihood & -2436 & -2436 & -2318 & -2246 \\
\hline Pseudo $\mathrm{R}^{2}$ & 0.149 & 0.148 & 0.189 & 0.214 \\
\hline Number of clusters & & 147 & & 147 \\
\hline Year-country dummies & Yes & Yes & Yes & Yes \\
\hline Bank dummy & No & No & No & Yes \\
\hline Cluster by bank ID & - & Yes & - & Yes \\
\hline Month dummy & - & - & Yes & Yes \\
\hline
\end{tabular}

Notes: This table reports the estimated coefficients and robust t-statistics in parentheses from various specifications of the ordered probit model of Equation 1 (see Section 4.3). The credit rating dataset consists of monthly sovereign and bank ratings for 147 banks originating from 42 countries for the period January 2006January 2013. The dependent variable is $\triangle B A N K$. The variable definitions and summary statistics are presented in Table 3. Fixed effects are included ("Yes"), not included ("No") or not applicable in given specification ("-"). The year-country fixed effect is the interaction term among the full set of country and year dummies. The month fixed effect is applied for every (but one) month during the sample period. Significance levels are: ${ }^{* * *} \mathrm{p}<1 \%$, ${ }^{* *} \mathrm{p}<5 \%,{ }^{*} \mathrm{p}<10 \%$. 
Table 6

Marginal effects for Table 5 estimations

\begin{tabular}{|c|c|c|c|c|c|c|c|c|c|}
\hline \multirow[b]{2}{*}{ Variables } & \multirow[b]{2}{*}{ Coefficient } & \multirow[b]{2}{*}{ t-value } & \multicolumn{6}{|c|}{ Marginal effect \% } & \multirow[b]{2}{*}{3} \\
\hline & & & -3 & -2 & -1 & 0 & 1 & 2 & \\
\hline \multicolumn{10}{|c|}{ Panel A- MODEL I } \\
\hline Post*Treatment & $-0.599 * * *$ & -4.87 & 0.79 & 0.93 & 1.85 & -2.23 & -0.76 & -0.39 & -0.18 \\
\hline$\Delta$ SovR & $0.398 * * *$ & 12.81 & -0.28 & -0.38 & -0.85 & 0.21 & 0.72 & 0.39 & 0.20 \\
\hline BankR & $0.048^{* * *}$ & 6.30 & -0.03 & -0.05 & -0.10 & 0.03 & 0.09 & 0.05 & 0.02 \\
\hline \multicolumn{10}{|c|}{ Panel B- MODEL II } \\
\hline Post*Treatment & $-0.599 * * *$ & -4.18 & 0.79 & 0.93 & 1.85 & -2.23 & -0.76 & -0.39 & -0.18 \\
\hline$\Delta$ SovR & $0.398 * * *$ & 11.83 & -0.28 & -0.38 & -0.85 & 0.21 & 0.72 & 0.39 & 0.20 \\
\hline BankR & $0.048^{* * *}$ & 6.01 & -0.03 & -0.05 & -0.10 & 0.03 & 0.09 & 0.05 & 0.02 \\
\hline \multicolumn{10}{|c|}{ Panel C- MODEL III } \\
\hline Post*Treatment & $-0.453 * * *$ & -2.66 & 0.31 & 0.46 & 1.08 & -0.98 & -0.51 & -0.25 & -0.11 \\
\hline$\Delta$ SovR & $0.394 * * *$ & 11.66 & -0.16 & -0.27 & -0.69 & 0.09 & 0.59 & 0.30 & 0.14 \\
\hline BankR & $0.035^{* * *}$ & 4.99 & -0.01 & -0.02 & -0.06 & 0.01 & 0.05 & 0.03 & 0.01 \\
\hline \multicolumn{10}{|c|}{ Panel D- MODEL IV } \\
\hline Post*Treatment & $-0.694 * * *$ & -2.73 & 0.47 & 0.74 & 1.73 & -1.98 & -0.59 & -0.27 & -0.11 \\
\hline$\Delta$ SovR & $0.392 * * *$ & 10.50 & -0.12 & -0.22 & -0.59 & 0.06 & 0.52 & 0.25 & 0.11 \\
\hline BankR & $0.134 * * *$ & 5.38 & -0.04 & -0.08 & -0.20 & 0.02 & 0.18 & 0.08 & 0.04 \\
\hline
\end{tabular}

Notes: This table presents the impact of three main variables on the probability of bank rating change (MEs: marginal effects) resulting from Equation 1 (see Table 5). Panels A, B, C and D present the MEs results from Models I-IV, respectively. Significance levels are: ${ }^{* * *} \mathrm{p}<1 \%,{ }^{* *} \mathrm{p}<5 \%,{ }^{*} \mathrm{p}<10 \%$. 
Table 7

\begin{tabular}{|c|c|c|c|}
\hline Model & (IV) & (IV) & (IV) \\
\hline Variables & f1. & f2. & f3. \\
\hline \multirow[t]{2}{*}{ Placebo } & 0.4204 & -0.1481 & -0.0460 \\
\hline & (0.99) & $(-0.60)$ & $(-0.26)$ \\
\hline \multirow[t]{2}{*}{$\Delta$ SovR } & $0.3959 * * *$ & $0.4026^{* * *}$ & $0.4071^{* * *}$ \\
\hline & $(10.80)$ & (10.86) & (11.10) \\
\hline \multirow[t]{2}{*}{ BankR } & $0.1419 * * *$ & $0.1450^{* * *}$ & $0.1504 * * *$ \\
\hline & $(5.56)$ & $(5.81)$ & $(5.87)$ \\
\hline \multirow[t]{2}{*}{$\ln$ (Assets) } & $-0.6731 * * *$ & $-0.7187 * * *$ & $-0.7263 * * *$ \\
\hline & $(-5.06)$ & $(-5.63)$ & $(-5.73)$ \\
\hline \multirow[t]{2}{*}{ LEVERAGE } & -0.0215 & -0.0206 & $-0.0248 *$ \\
\hline & $(-1.54)$ & $(-1.46)$ & $(-1.78)$ \\
\hline \multirow[t]{2}{*}{ ROAE } & $-0.0130 * * *$ & $-0.0130 * *$ & $-0.0114^{* *}$ \\
\hline & $(-2.60)$ & $(-2.44)$ & $(-2.33)$ \\
\hline \multirow[t]{2}{*}{ LLR/GL } & -0.0215 & -0.0119 & -0.0153 \\
\hline & $(-1.54)$ & $(-0.54)$ & $(-0.66)$ \\
\hline \multirow[t]{2}{*}{ INCREV } & 0.0026 & 0.0036 & 0.0039 \\
\hline & $(0.43)$ & $(0.61)$ & $(0.66)$ \\
\hline Observations & 8702 & 8512 & 8330 \\
\hline Log likelihood & -2215 & -2165 & -2119 \\
\hline Pseudo R ${ }^{2}$ & 0.217 & 0.218 & 0.221 \\
\hline Number of bank clusters & 144 & 144 & 144 \\
\hline Year -country dummies & Yes & Yes & Yes \\
\hline Bank dummy & Yes & Yes & Yes \\
\hline Month dummy & Yes & Yes & Yes \\
\hline
\end{tabular}

Notes: The table presents the estimated coefficients and robust t-statistics in parentheses from results of falsification tests performed on Model IV of Equation 1 (seen in Table 5) using the ordered probit model estimation on the sample of 147 banks from 42 countries for the period January 2006 - January 2013 (see Section 6.1). The dependent variable is $\triangle B A N K$. f.1; f.2; f.3 are leads in which the treatment was assigned (1, 2 and 3 months earlier than the disclosures were announced, respectively). This serves the purpose of a "placebo effect". The variable definitions and summary statistics are presented in Table 3 . The year-country fixed effect is the interaction term among the full set of country and year dummies. The month fixed effect is applied for every (but one) month during the sample period. Significance levels are: ${ }^{* *} \mathrm{p}<1 \%,{ }^{* *} \mathrm{p}<5 \%,{ }^{*} \mathrm{p}<10 \%$. 
Table 8

Placebo effects - cross-section variation (Model IV)

\begin{tabular}{|c|c|c|c|c|c|c|}
\hline \multirow[b]{2}{*}{ Variables } & \multicolumn{3}{|c|}{$\begin{array}{c}\text { Panel A } \\
\text { Subset of banks }\end{array}$} & \multicolumn{3}{|c|}{$\begin{array}{c}\text { Panel B } \\
\text { All banks }\end{array}$} \\
\hline & 1 & 2 & 3 & 1 & 2 & 3 \\
\hline \multirow{2}{*}{ Placebo } & 0.1421 & -0.0687 & -0.0328 & -0.4805 & 0.5946 & -0.2955 \\
\hline & $(0.70)$ & $(-0.39)$ & $(-0.21)$ & $(-0.88)$ & $(1.40)$ & $(-0.70)$ \\
\hline \multirow[t]{2}{*}{$\Delta$ SovR } & $0.3843 * * *$ & $0.3849 * * *$ & $0.3849 * * *$ & $0.3851^{* * *}$ & $0.3873 * * *$ & $0.3833^{* * *}$ \\
\hline & (7.73) & (7.73) & (7.74) & (7.73) & (7.75) & $(7.66)$ \\
\hline \multirow[t]{2}{*}{ BankR } & $0.1475^{* * *}$ & $0.1473^{* * *}$ & $0.1482^{* * *}$ & $0.1487 * * *$ & $0.1466 * * *$ & $0.1483^{* * *}$ \\
\hline & (4.17) & $(4.12)$ & $(4.20)$ & (4.33) & $(4.12)$ & $(4.24)$ \\
\hline \multirow{2}{*}{$\ln$ (Assets) } & 0.5231 & $0.5376^{*}$ & $0.5299 *$ & 0.5233 & $0.6075^{*}$ & 0.4821 \\
\hline & (1.61) & (1.67) & (1.65) & (1.63) & (1.83) & $(1.50)$ \\
\hline \multirow[t]{2}{*}{ LEVERAGE } & $0.0447 * *$ & $0.0409 *$ & $0.0404^{*}$ & $0.0418 *$ & 0.0348 & $0.0445^{* *}$ \\
\hline & (1.98) & $(1.87)$ & (1.86) & $(1.92)$ & $(1.55)$ & $(2.01)$ \\
\hline \multirow[t]{2}{*}{ ROAE } & -0.0028 & -0.0026 & -0.0031 & -0.0029 & -0.0053 & -0.0019 \\
\hline & $(-0.49)$ & $(-0.42)$ & $(-0.53)$ & $(-0.50)$ & $(-0.80)$ & $(-0.33)$ \\
\hline \multirow[t]{2}{*}{ LLR/GL } & -0.0044 & -0.0055 & -0.0059 & -0.0056 & -0.0067 & -0.0055 \\
\hline & $(-0.20)$ & $(-0.25)$ & $(-0.27)$ & $(-0.25)$ & $(-0.30)$ & $(-0.25)$ \\
\hline \multirow[t]{2}{*}{ INCREV } & -0.0101 & -0.0101 & -0.0099 & -0.0099 & -0.0096 & -0.0101 \\
\hline & $(-1.22)$ & $(-1.22)$ & $(-1.20)$ & $(-1.20)$ & $(-1.17)$ & $(-1.22)$ \\
\hline Observations & 4050 & 4050 & 4050 & 4050 & 4050 & 4050 \\
\hline Log likelihood & -1119 & -1120 & -1120 & -1119 & -1118 & -1119 \\
\hline Pseudo $\mathrm{R}^{2}$ & 0.228 & 0.228 & 0.228 & 0.228 & 0.229 & 0.228 \\
\hline Number of bank clusters & 70 & 70 & 70 & 70 & 70 & 70 \\
\hline Year-country dummies & Yes & Yes & Yes & Yes & Yes & Yes \\
\hline Bank dummy & Yes & Yes & Yes & Yes & Yes & Yes \\
\hline Month dummy & Yes & Yes & Yes & Yes & Yes & Yes \\
\hline
\end{tabular}

Notes: The table presents the estimated coefficients and robust t-statistics in parentheses from results of falsification test performed on Model IV of Equation 1 (seen in Table 5) using the ordered probit model estimation on the sample of 147 banks from 42 countries for the period January 2006- January 2013 (see Section 6.1). The dependent variable is $\triangle B A N K$. The variable definitions and summary statistics are presented in Table 3. The test in Panel A randomly assigns the placebo to a subset of banks which belong to the control group sovereigns. The test in Panel B randomly selects sovereigns which belong to the control group and assigns placebo to all banks belonging in that subset. The results of three consecutive trials are presented in columns 1 , 2 and 3 of Panels A and B. The sample is restricted to the control group only and for this reason the number of observations is constant in all trials. The year-country fixed effect is the interaction term among the full set of country and year dummies. The month fixed effect is applied for every (but one) month during the sample period. Significance levels are: ${ }^{* * *} \mathrm{p}<1 \%,{ }^{* *} \mathrm{p}<5 \%,{ }^{*} \mathrm{p}<10 \%$. 
Table 9

Balancing test- Propensity Score Matching

Mean

\begin{tabular}{|c|c|c|c|c|c|c|c|}
\hline \multirow{2}{*}{ Variable } & & \multicolumn{2}{|c|}{ Mean } & \multirow{2}{*}{$\%$ bias } & \multirow{2}{*}{$\begin{array}{r}\% \text { reduct } \\
\mid \text { bias } \mid\end{array}$} & \multicolumn{2}{|c|}{ t-test } \\
\hline & & Treated & Control & & & $\mathrm{t}$ & $\mathrm{p}>\mathrm{t}$ \\
\hline \multirow{2}{*}{ SOV20SCALE } & Unmatched & 16.360 & 15.357 & 25.4 & & 8.74 & 0 \\
\hline & Matched & 16.360 & 16.426 & -1.7 & 93.4 & -0.48 & 0.628 \\
\hline \multirow[t]{2}{*}{ BANK20SCALE } & Unmatched & 13.598 & 12.845 & 24.5 & & 7.94 & 0 \\
\hline & Matched & 13.598 & 13.752 & -5.0 & 79.6 & -1.59 & 0.113 \\
\hline \multirow[t]{2}{*}{$\ln$ (Assets) } & Unmatched & 18.673 & 18.009 & 37.4 & & 12.76 & 0 \\
\hline & Matched & 18.673 & 18.734 & -3.4 & 90.9 & -0.99 & 0.322 \\
\hline \multirow[t]{2}{*}{ LEVERAGE } & Unmatched & 16.283 & 14.923 & 20.9 & & 7.2 & 0 \\
\hline & Matched & 16.283 & 16.118 & 2.5 & 87.9 & 0.72 & 0.470 \\
\hline \multirow[t]{2}{*}{ LLR/GL } & Unmatched & 2.5377 & 2.9592 & -15.1 & & -4.91 & 0 \\
\hline & Matched & 2.5377 & 2.5937 & -2.0 & 86.7 & -0.71 & 0.477 \\
\hline \multirow[t]{2}{*}{ MEANCPI } & Unmatched & 2.2738 & 3.3611 & -141.6 & & -39.8 & 0 \\
\hline & Matched & 2.2738 & 2.2716 & 0.3 & 99.8 & 0.23 & 0.821 \\
\hline
\end{tabular}

Notes: The table presents results of a balancing exercise performed directly after the propensity score matching (see Section 6.2). The null hypothesis states that difference in means of covariates is equal to zero. Variable definitions and summary statistics are presented in Table 3. Additionally: SOV20SCALE (BANK20SCALE) is sovereign (bank) credit rating based on the 20-notch scale; CPI is the Consumer Price Index and MEANCPI takes the mean value per sovereign.

We require that the difference between the propensity score of the control and treatment group (caliper) does not exceed $1 \%$ in absolute value therefore only covariates which fulfil this assumption are included in the score (ROAE and INCREV from our main regression analysis were excluded). 

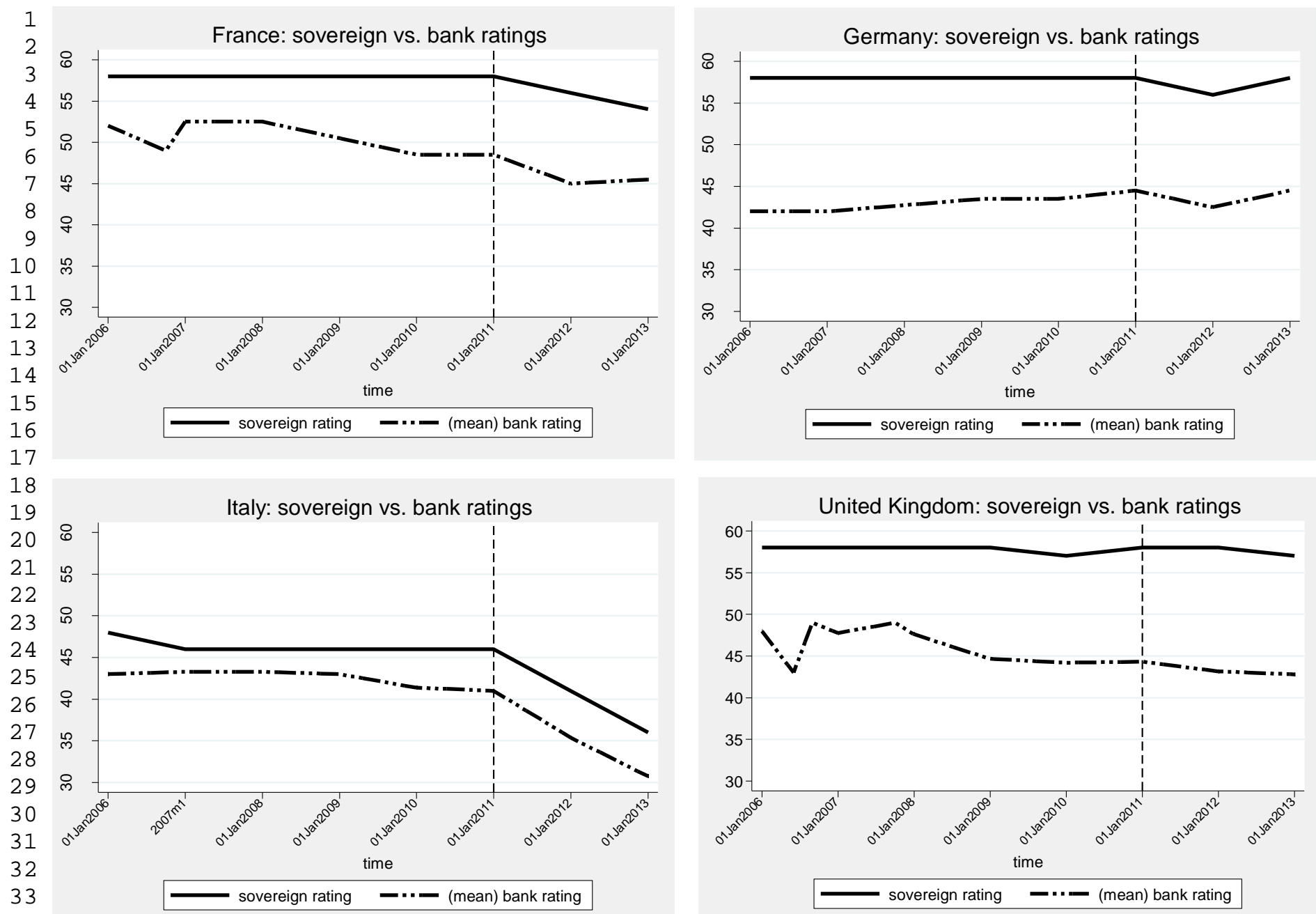

United Kingdom: sovereign vs. bank ratings

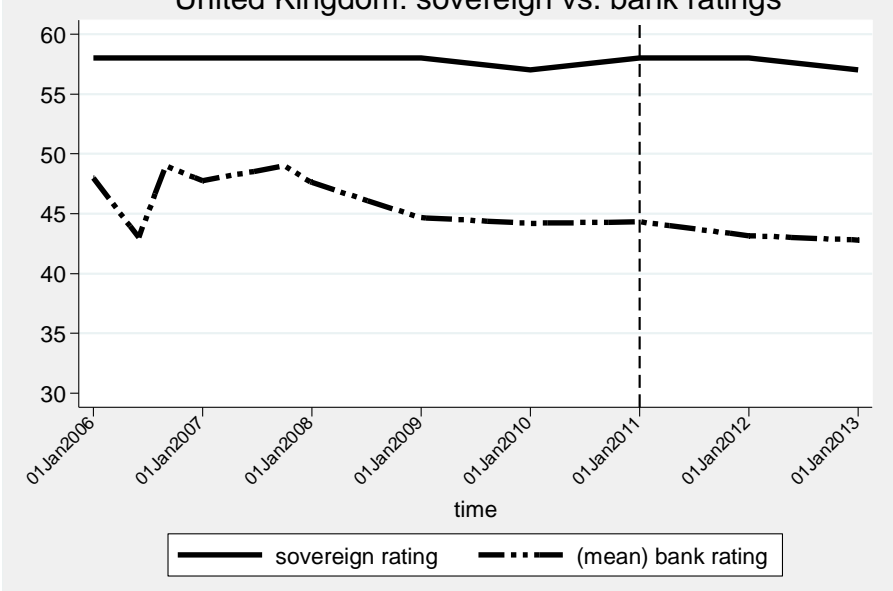

Fig. 1. Trends between sovereign and bank ratings (Four examples)

Notes: This figure represents the trend between sovereign and bank ratings for a sample of four sovereigns from the treatment group during the sample period (January 2006 to January 2013). The sovereign (thick) line represents the sovereign rating while the bank rating (dash dot) line corresponds to the average rating of the listed financial institutions incorporated in that country. The dashed (vertical) line represents the timing of the regulatory change to disclose the solicitation status of the sovereign rating. The credit ratings scale is transformed into a 58-point rating scale. 